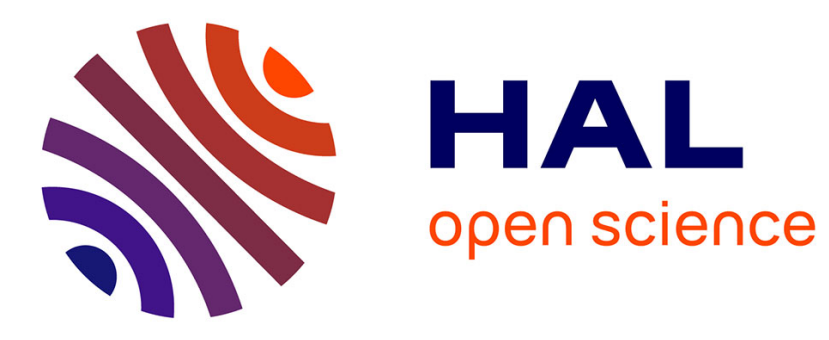

\title{
Prenatal Infancy Regained: Great Peace (Taiping) Views on Procreation and Life Cycles
}

Grégoire Espesset

\section{To cite this version:}

Grégoire Espesset. Prenatal Infancy Regained: Great Peace (Taiping) Views on Procreation and Life Cycles. Anna Andreeva; Dominic Steavu. Transforming the Void: Embryological Discourse and Reproductive Imagery in East Asian Religions, Brill, pp.53-86, 2015, 9789004306523. 10.1163/9789004306523_003. halshs-01385128

\section{HAL Id: halshs-01385128 \\ https://shs.hal.science/halshs-01385128}

Submitted on 7 Dec 2021

HAL is a multi-disciplinary open access archive for the deposit and dissemination of scientific research documents, whether they are published or not. The documents may come from teaching and research institutions in France or abroad, or from public or private research centers.
L'archive ouverte pluridisciplinaire HAL, est destinée au dépôt et à la diffusion de documents scientifiques de niveau recherche, publiés ou non, émanant des établissements d'enseignement et de recherche français ou étrangers, des laboratoires publics ou privés. 


\title{
Transforming the Void
}

\section{Embryological Discourse and Reproductive Imagery in East Asian Religions}

\author{
Edited by
}

Anna Andreeva and Dominic Steavu

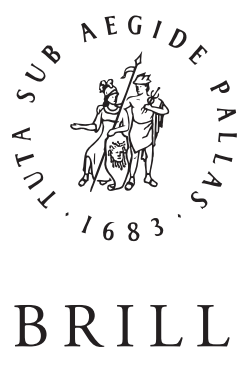

LEIDEN | BOSTON 


\section{Contents}

Acknowledgements IX

List of Figures and Tables XI

Conventions and Abbreviations XIV

List of Contributors XVI

Introduction: Backdrops and Parallels to Embryological Discourse and Reproductive Imagery in East Asian Religions 1

Anna Andreeva and Dominic Steavu

\section{PART 1}

\section{China}

1 Prenatal Infancy Regained: Great Peace (Taiping) Views on Procreation and Life Cycles 53

Grégoire Espesset

2 Conceiving the Embryo of Immortality: "Seed-People" and Sexual Rites in Early Taoism 87

Christine Mollier

3 Cosmos, Body, and Gestation in Taoist Meditation 111 Dominic Steavu

4 Symbolic Pregnancy and the Sexual Identity of Taoist Adepts 147 Catherine Despeux

5 Creation and Its Inversion: Cosmos, Human Being, and Elixir in the Cantong Qi (The Seal of the Unity of the Three) 186 Fabrizio Pregadio

6 On the Effectiveness of Symbols: Women's Bodies as Mandalas 212 Brigitte Baptandier 


\section{PART 2}

Japan

7 The Embryonic Generation of the Perfect Body: Ritual Embryology from Japanese Tantric Sources 253

Lucia Dolce

8 Buddhism Ab Ovo: Aspects of Embryological Discourse in Medieval Japanese Buddhism 311

Bernard Faure

9 "Human Yellow" and Magical Power in Japanese Medieval Tantrism and Culture 344

Nobumi Iyanaga

10 "Lost in the Womb": Conception, Reproductive Imagery, and Gender in the Writings and Rituals of Japan's Medieval Holy Men 420 Anna Andreeva

11 Embryology in Early Modern Sōtō Zen Buddhism 479 Kigensan Licha

12 Foetal Buddhahood: From Theory to Practice - Embryological Symbolism in the Autumn Peak Ritual of Haguro Shugendo 522 Gaynor Sekimori

Index $\quad 559$ 


\title{
Prenatal Infancy Regained: Great Peace (Taiping) Views on Procreation and Life Cycles
}

\author{
Grégoire Espesset
}

Great Peace (Taiping 太平) beliefs designate a set of ideas common to an unknown number of thinkers through a vaguely defined period of time - the first centuries of our era - which ultimately crystallised into a text, the Taiping jing 太平經 (Great Peace Scripture; DZ 1101), whose received version appears in the fifteenth-century Zhengtong Daozang 正統道藏 (Taoist Canon of the Zhengtong [Era]). ${ }^{1}$ My analysis of that version suggests that a common ideology pervading all its textual strata is what gives the Taiping jing its cohesion. ${ }^{2}$ On this assumption, the present study deals with the Taiping jing and related sources as a corpus of a satisfactory homogeneity, despite a problematic textual history and the material heterogeneity resulting from it. ${ }^{3}$

Somewhere between a theory of universal equilibrium and the praxis of its restoration, Great Peace ideology is not primarily focused on human physiology, procreation, and the physiological processes, but it nevertheless endeavours to deal with most of these themes, among many other topics, whenever the didactical need arises - personal harmony being as basic a requisite as cosmic order in the all-encompassing, multilayered Great Peace agenda. Therefore, although textual support is drawn from various thematically disconnected chapters and units of the scripture, the present chapter will

1 The Taoist Canon actually contains two versions, undated and anonymous: (a) the Taiping jing (DZ 1101, 35-119), which is incomplete and preceded by (b) an abridged rendition, the Great Peace Scripture Digest (Taiping jing chao 太平經鈔; DZ 1101, 1-10). Both were mistakenly numbered as a single text (DZ 1101) in Kristofer Schipper, ed., Concordance du Tao-tsang: Titres des ouvrages (Paris: École Française d'Extrême-Orient, 1975). The abbreviation Dz throughout the present study refers to this catalogue.

2 See Grégoire Espesset, "Cosmologie et trifonctionnalité dans l'idéologie du Livre de la Grande paix (Taiping jing)” (PhD dissertation, Université Paris Diderot-Paris 7, Paris, 2002c).

3 For a synthesis of the textual history of the Great Peace Scripture up to the Tang 唐 dynasty (618-907) and some of its problems, see Grégoire Espesset, "Le Livre de la Grande paix et son corpus: Histoire et structure littéraires, idéologie," Annuaire de l'École pratique des hautes études (EPHE), Section des sciences religieuses 117 (2008-2009). 
attempt to outline a coherent Great Peace approach to gestation and some uses of its imagery.

The first section below expounds quite peculiar views of human physiology and some of the practical advice given, using technical terminology, for successful impregnation. The next section relates gestation to the broader framework of ontology and cosmology. The third section examines the conceptions of prenatal infancy and emphasises the vulnerability of the unborn child to threats which modern rationality would hardly conceive of. The fourth section reviews evocations of the newborn in terms of both perfection and vulnerability, including evident references to the writings ascribed to Laozi 老子. The fifth section deconstructs the logic at work in a few instances of time cycles - inside and outside the Great Peace corpus (see below) - so as to shed light on the key point in their dynamics. Closing the teleological and heuristic sequence of the study, the last section shows how Great Peace ideologists imagined turning this dynamics to their own advantage in order to initiate a process of ontological reversion to the pristine condition of prenatal infancy - the ontological equivalent of chaos - and thus liberate themselves from the lethality of time.

As a counterpoint to Great Peace materials, this study will also venture briefly into a scriptural corpus of comparable antiquity, namely the Weft (wei 緯) writings, also known, albeit improperly, as the "Confucian Apocrypha" in Western academia. ${ }^{4}$ Although the Weft supposedly supplemented the official, Confucian "classics" (jing 經), they reflect ideas which are less orthodox than those expressed in the jing and are, more often than not, not quite on the same wavelength. Therefore, the second assumption of this study is that both the Great Peace corpus and Weft remnants should be seen, and used, as sources of an alternative knowledge to "Confucian" orthodoxy.

Even though the ideas expressed in both corpora are to be located on the margins of official ideology, they nevertheless share with it a cultural worldview. Their peculiarity would then rather lie in the way these corpora understand or interpret, and sometimes transform, elements from this common knowledge to articulate their own views. Thus Great Peace proponents adjusted the 'classic' heritage to which they were indebted in order to sustain their soteriological agenda. Through faith and strict observance - the

4 The most accessible introduction to the Weft sphere remains Jack L. Dull, "A Historical Introduction to the Apocryphal (Ch'an-wei) Texts of the Han Dynasty," (PhD dissertation, University of Washington, Seattle, 1966). Weft textual references will be to the modern Japanese critical edition: Yasui Kōzan 安居香山 and Nakamura Shōhachi 中村璋八, eds., Chōshū Isho shūsei 重修緯書集成 (Tokyo: Meitoku shuppansha, 1971-1992). 
fundamental components of their new religious ideology - they transcended the knowledge they had inherited from the technicians of pre-imperial and early imperial China.

Somewhat bluntly titled "Yang is Venerable, Yin is Menial" (Yang zun yin bei 陽尊狯卑”), unit 138 (chapter 93) of the Taiping jing includes an original view of reproductive organs and the process of impregnation. ${ }^{5}$ Basically, the binary assumption is that Yang (that is, all things male) "is full and has substance" while Yin (all things female) "is empty and has no substance." ${ }^{\prime}$ The text first addresses male reproductive organs, referred to as "that whereby the mandate [of life] is conferred."7 The upper part of the male organs (the penis), which corresponds to Great Yang (taiyang 太陽) and, as such, echoes the generative function (sheng 生) of Heaven, "is full and has a surplus." stantly spreads downward; it is amassed in the left and right lower parts (the testicles), which correspond to Great Yin (taiyin 太陰) and whose "linear patterns" (wenli 文理) - meaning the inner structure of the testicles, or possibly the surface of the scrotum - echo the network of footpaths delineating fields on Earth. The descending "surplus" gives each testicle its own "substance" (shi 實), a word here to be understood also as "a nucleus" (he 核). The description is specific enough to add that the left "nucleus" corresponds to "humans" (ren 人) and the right one, to the "myriad beings" (wanwu 萬物). The conclusion is that the male reproductive organ is both "venerable and noble." ${ }^{\prime \prime}$ By contrast, the female organ is referred to as "the place where the mandate [of life] is received,"

5 The extant Taiping jing is organised into numbered chapters (juan 卷) without titles, divided into numbered units bearing titles (see also n. 20 below). Both numerical sequences have lacunae. In most cases, unit titles reflect closely the textual contents of units - but, interestingly, it is not always so, as we shall see; some titles possibly reflect later editorial alterations. The extant Taiping jing being certainly the conflation of the literary production of different persons from different eras, hence a heterogeneous source, it is preferable to refer to both the chapter and unit numberings, and to indicate unit titles precisely, rather than referring to the text en bloc (for instance, to the sole page numbering of a modern edition) as if it were a textually homogeneous source.

6 盈滿而有實 and 虛空而無實, respectively; Taiping jing DZ 1101, 93.4a-5a (unit 138). Unless otherwise noted, all translations to English are my own and remain tentative.

7 所以(受) [授] 命者; ibid.

8 盈滿而有餘; ibid.

9 尊而貴; ibid. 
and is briefly described as "an opening both empty and void, without fullness, surplus nor substance," hence "lowered and despised."10

These prolegomena are followed by an explanation of the impregnation process. A disciple wonders how a woman may become pregnant since, as the master just stated, her reproductive organ is devoid of any "substance" (shi). To this, the master answers:

Yin is fundamentally empty. Only once Yang has spread and transformed substance in the middle of Yin - which, being menial and despicable, fears Yang - does Yin obediently nourish it, not daring to reject [it] ... Now the vulgar say that Yang generates and Yin develops, [yet] Yin only follows, nourishing and developing the Yang substance. ${ }^{11}$

狯本虛空, 但陽往施化實於陰中, 而狯卑賤畏陽, 順而養之, 不敢去也 ... 今俗者, 言陽生䧀成, 但陰隨而養成陽實也。

The master then resumes his lecture by applying the same binary logic to all life forms (the "myriad beings") - first plants, then animals. ${ }^{12}$

Practical guidelines for impregnation, which could be taken straight out of a manual on the "arts of the bedchamber" (fangzhong shu 房中術), are expounded in a passage missing from the received scripture but cited extensively in a seventh-century source. ${ }^{13}$ The citation is in the form of a dialogue between a "real person" (zhenren 真人), here referring to a disciple, and his master. Asked why so few children are born, the master offers the following answer:

It is only that impregnation is [attempted] thoughtlessly. In the event that one impregnates a person willing to conceive, one opens her jade door and spreads semen within - it is like sowing the earth in springtime; ten times out of ten, the response is harmonious and [plants] come up. Untimely impregnation is like sowing seeds during the tenth month [in

10 所受命處; 戶空而虛, 無盈餘又無實; and 見卑且賤, respectively; Taiping jing DZ 1101, 93.4a-5a (unit 138).

11 Ibid., 93.5b-6a.

12 Ibid., 93.6a-b.

13 Namely, the 676 commentary to the official dynastic history of the Eastern Han 東漢 (25-220) composed by Li Xian 李賢 (651-684) and his scholarly entourage. Following his elder brother's death, Li Xian became heir apparent $\left(675^{-680}\right)$ but was subsequently demoted to commoner status and soon forced to commit suicide. He was given the posthumous title Prince Zhanghuai 章懷太子 in 711 . 
winter]; ten times out of ten, they perish to the last and certainly nothing sprouts forth. ${ }^{14}$

但施不得其意耳. 如令施其人欲生也, 開其玉戶, 施種於中, 比若春種於 地也, 十十相應和而生. 其施不以其時, 比若十月種物於地也, 十十盡死, 固無生者。

At the disciple's request, the master adds:

Suppose that a woman without children, even when [semen] is spread within her a hundred times a day, still conceives nothing. Not to reach the place where conception occurs is such as this. For this reason did the sages and the wise men of antiquity not recklessly sow a sterile earth. This is called wasting semen and exhausting pneuma ${ }^{15}$ without producing anything. ${ }^{16}$

今無子之女, 雖日百施其中, 猶無所生也. 不得其所生之處, 比若此矣. 是 故古者, 聖賢不妄施於不生之地也. 名爲亡種竭氣而無所生成。

According to the master, a successful impregnation would depend on two factors: first, the fertility of the female partner (the eventuality of male sterility is not alluded to); second, the timeliness of sexual intercourse. In both cases, remarkably, we note that the master almost instantly resorts to the imagery of agricultural production.

\section{2 The Symbolism of Gestation}

A triadic cosmology based on Yin, Yang, and Central Harmony (zhonghe 中和) pervades the Taiping jing, ${ }^{17}$ whose penultimate unit (unit 212) explains:

14 Hou Han shu 後漢書 (Book of the Later Han), by Fan Ye 范曄 (398-445), 30B.1081.

15 In Chinese metaphysics, $q i$ 氣, also rendered as "vapour," "breath," or "energy," is the basic cosmic constituent of all things, as well as a particularised form of the macrocosmic materia prima (see n. 65 below). See the discussion by Ulrich Libbrecht, "Prāna - pneuma - ch'i?" in Thought and Law in Qin and Han China: Studies Dedicated to Anthony Hulsewé on the Occasion of his Eightieth Birthday, Wilt L. Idema and Erik Zürcher, eds. (Leiden: Brill, 1990).

16 Hou Han shu, 3oB.1081.

17 According to Dany-Robert Dufour, Les Mystères de la trinité (Paris: Gallimard, 1990), 143, any threefold grouping comes under the category of either "trichotomy" (a classification), 
Yin and Yang unite and conceive in the middle. Therefore, gestation generally takes place below the head and above the feet, in the central, abdominal [part of the mother's body]. ${ }^{18}$

陰陽合生於中央, 故凡懷妊者, 在頭下足上, 中腹而居。

In view of this statement, one would expect Central Harmony - a concept denoting at once the logical middle, the cosmic sphere between Heaven and Earth, and the human sphere - to symbolically preside over gestation, yet unit 134 informs us otherwise: this tasks lies with Yin. The text first explains that deaths from burns (Fire; Yang) are caused by Heaven (Yang), before turning to deaths by drowning (Water; Yin), which, we are told, are caused by Earth (Yin):

Earth is the lowness of Yin. Water is the intensity of Yin and belongs to Earth. Yin presides over gestation. Generally, when beings are harmed while pregnant, there will be bleeding. Blood is in the category of Water. [Any living being] harmed while pregnant will be angry and displeased; furthermore, by bleeding, it will perpetrate pollution and harm [other] people. Watercourses, being the blood vessels of Earth, are the Yin of Earth. When angry, Yin, being menial, will attack and kill people by this personification. ${ }^{19}$

地者, 䧀之卑. 水者, 䧀之劇者也, 屬地. 䧀者, 主懷姙. 凡物懷姙而傷者, 必 爲血. 血者, 水之類也. 懷姙而傷者, 必怒不悦, 更以其血行汗傷人. 水者, 乃地之血脉也, 地之陰也. 陰者, 卑, 怒必以其身行戰闘殺人。

Although the general Yin/Yang logic underlying the discourse is familiar from many other sources, this passage is novel in many regards. For the present purpose, it informs us that it is Yin, rather than Central Harmony (the middle) as one may have expected, that symbolically presides over gestation. It also hints at the polluting and damaging properties of blood, without elaborating on the

"triad" (a logic relation), "ternarity" (a diachronic succession), or "trinity" (a synchronic ensemble). Triplets always imply a logic relation between their components in Great Peace ideology, therefore I mostly use "triad" (and its adjectival form "triadic") in my work - plus "ternarity" in a few specific instances, such as "upper, middle and lower ages" (shanggu zhonggu xiagu 上古中古下古). However, in Great Peace ideology, the triad permanently assumes multiple forms, somewhat as in Saint Augustine's (354-430) theological concept of Trinity.

19 Ibid., 92.7a (unit 134). 
topic. Furthermore, the passage documents how natural accidents (here death by drowning) were interpreted as the effect of some retaliation on the part of cosmic principles in a particularised form (here Yin particularised as watercourses).

In addition, the passage is fully consistent with unit 61 of the Taiping jing, where Earth is compared to a mother's body. Entitled "Soil Excavation and Issuing the [Master's] Writings" (“Qitu chushu 起土出書”), the received version of unit 61 may well have inherited textual fragments from other units, today lost, of the Taiping jing. ${ }^{20}$ Since Earth and mother both belong to the Yin position in their respective triads, namely Heaven-Earth-Human (tian di ren 天 地人) and father-mother-child (fu mu zi 父母子), they naturally serve comparative purposes - Earth is the mother of mankind. As such, the cosmic principle of Earth should be respected in the same way as a pregnant woman, ${ }^{21}$ and her corporeal form, the earth, should be handled with the proper care and deference. Soil, rocks, ground water, and water are Earth's flesh, bones, blood vessels, and blood, respectively. Thus, special measures are enforced for excavation projects related to building houses or sinking wells. As a general rule, the text proscribes digging deeper than three feet, and even less deep next to rivers or seashores, where the skin of Earth is assumed to be thinner. Ideally, according to the unit, people should solely dwell in natural caves - although houses built on shallow foundations are tolerated because they do not penetrate Earth's surface too profoundly - and drink water from natural springs and watercourses. ${ }^{22}$

20 According to a table of contents preserved in a Dunhuang 敦煌 manuscript, the sixthcentury Great Peace Scripture was, in its fullest form, divided into 170 chapters (juan), which were organised into ten parts ( $b u$ 部) numbered according to the celestial stems; each part contained seventeen chapters and each chapter, a varying number of unit, for a grand total of 366 units. Chapter 154 from Part 10 (gui bu 癸部, a part entirely missing in the canonical version) comprised the following units: no. 319, “Jin fantu 禁犯土” ("Proscription on Offending the Soil"); no. 320, "Yongfang 䔨防” (“Blockages”); no. 321, "Qu tu sanchi 取土三尺” (“Taking Three Feet of Soil”); no. 322, “Zhi tu bing ren 治土病人” (“Regulating Soil Causes Illness”); and no. 323, “Tu bu ke fu fan 土不可復犯” (“The Soil May Not Be Offended Anymore"); see [Taiping bu juan di er] 太平部卷第二 (Great Peace Part, chapter 2), MS Stein 4226, cols. 265-66. All of these themes strongly echo the contents of unit 61. However, it is not uncommon for different units in the Taiping jing to take up similar themes, so the possibility that textual transfers occurred from these lost units to the canonical unit 61 must remain hypothetical.

21 有胞中之子; Taiping jing DZ 1101, 45.1a-13a (unit 61). Ibid. The entire unit is translated in Barbara Hendrischke, The Scripture on Great Peace: The Taiping jing and the Beginnings of Daoism (Berkeley: University of California Press, 2006), 256-73. 
This interpretation of Earth as a mother, whom people must respect as such, brings us back to the Golden Age of pristine humanity - a recurring theme throughout the Taiping jing - when the material development of human civilisation was still limited.

Prenatal infancy may have been considered a realm of boundless potentiality in early imperial China as much as in the typical parental expectations of our time. In unit 182 of the Taiping jing, we read that as early as the uterine stage, the patronym and given name (xingming 姓名) of some people already appear on a "record of the non-dying" (busizhi lu 不死之錄) kept by deities in Heaven. First, this early promise of immortality is to be fulfilled on condition of unfailing virtuous conduct throughout one's lifetime - and, quite adequately, the unit focuses on two ontological categories embodying high morality, the benevolent (shan 善) and the humane (ren 仁). Only then, providing that a divine guarantor (baozhe 保者) recommends them, deserving individuals eventually enjoy the bliss of ascension to Heaven to serve in the divine bureaucracy. $^{23}$

However, such idealistic and metaphorical representations of the child in the Taiping jing (some of which can also be found in other early Taoist works) are somewhat counterbalanced by other images commonly linked to prenatal infancy - although the use of these images seems to be, at least in some instances, mainly rhetorical. In unit 139, in order to warn disciples against the dangers of ignorance, the master draws an analogy with the mental condition of the unborn child and its total dependence on its mother:

It is like an unknowing infant [who], still in the womb, goes around following its mother's person. How could it know that the Heavenly Way is vast, far-reaching, and without confines ${ }^{24}$

比若嬰兒蒙蒙, 未出胞中, 隨其母身而行, 安知天道廣遠而無方?

The child's ignorance, of course, does not contain the seeds of peril, as adult ignorance does - the impossibility to obtain the Way and an increased likelihood to fall into perversity (xie 邪). Prenatal ignorance is part and parcel of a

23 Ibid., 111.9b (unit 182).

24 Ibid., 93.17b (unit 139). 
pristine original human condition, whereas adult ignorance betrays a moral defect. Prenatal ignorance is but a temporary condition, and we shall see how it should be dealt with after birth.

Another notion commonly linked to prenatal life is its frailty. Unit 212, which stresses that the domination of the generative power of Yang cannot accept any interference from the "lethal pneumata" (shaqi 殺氣) of Yin, calls up the notion of frailty, together with the child's value as the guarantor of an unbroken family lineage:

It is like a child in the womb. There can be not [even] minor damage, [otherwise the child will] inevitably be injured and die; once dead it would not revive, and, inevitably, a person will be lost. If such continuous injuring [of unborn children] does not cease, then [an entire lineage] becomes extinct and is deprived of later generations. A family without lineage is [thus] eradicated. ${ }^{25}$

比若胞中之子, 不可有小害, 輙傷死. 死不復生, 輙棄一人. 爲是連傷而不 止, 便絕滅無後世矣. 一家無統絕去矣。

Since the house of Han had to face succession crises due to emperors dying without heir, this image was probably intended for imperial consideration as well - if not primarily. This concern for the frailty of the unborn child is apparent in a passage from another unit (unit 41), where the master denounces female infanticide: ${ }^{26}$

Suppose that, in the realm, a single family kills one female [newborn]; how many hundreds of thousands of families [there are] in the realm! Sometimes a dozen females get killed in a single family; sometimes pregnant [women] are injured even before giving birth. Their pneuma, stricken by injustice, ascends and moves Heaven. How can there be such nonsense? ${ }^{27}$

今天下一家殺一女, 天下幾億家哉! 或有一家乃殺十數女者, 或有姙之未 生出反就傷之者, 其氣冤結上動天, 奈何無道理乎?

25 Ibid., 119.2a (unit 212).

26 The Taiping jing would seem to be the earliest surviving source in Chinese to express such a concern, albeit on cosmological rather than humanistic grounds; see Hendrischke, 2006, 68-69.

Taiping jing DZ 1101, 35.7b (unit 41). Compare Hendrischke, 2006, 75 . 
Due to this frailty, prenatal infancy may not be safely considered a state of Edenic grace. Furthermore, even if a pregnant woman were carefully protected, her womb would still be threatened by the harmful consequences of ancestral mischief. Unit 185, which belongs to a minor textual stratum of the received version of the scripture, bears the title "Lusting for Riches and Sensuality [Provokes] Calamities Extending to [Unborn Descendants] in the Womb."28 The title is fully developed in the following sentence, which bemoans the consequences of deceased ancestors' misconduct:

Those who lust for riches and sensuality disregard the resulting hardships - calamities extending to [unborn descendants] in the womb, [who] will never see the sun, moon and stars. What a painful grief! ${ }^{29}$

\section{其領財色, 不顧有患, 災及胞中, 不見日月星. 何惜痛乎!}

The warning is closely related to the theme of "inherited burden" (chengfu 承負), an expression referring to the accumulation of all sorts of problems on various levels - cosmic, collective, familial, and individual - caused by the misconduct of past generations, and which the present generation, whether itself responsible for additional misdeeds or not, must face up to. ${ }^{30}$ This relationship between prenatal death and "inherited burden" is confirmed in a unit devoted to "Explaining (and Relieving) Inherited Burden" ("Jie chengfu” 解承負). Absent from the canonical version of the Taiping jing, this unit has survived in shortened form in the Taiping jing chao 太平經鈔 (Great Peace Scripture Digest; DZ 1101). Typical of Great Peace triadic logic, the passage first defines three orders of duration applying to the cumulative effects of "inherited burden" (30,000 years for the sovereign; 3,000 years for ministers; and 300 years for commoners), then three lengths of human lifespan (a superior longevity of 120 years corresponding to Heaven, an average longevity of 80 years corresponding to Earth, and an inferior longevity of 60 years corresponding to Central Harmony). The text then adds:

If [one] incessantly practises benevolence and surpasses these [orders of] longevity, it is called "to pass through generations." [Those who] incessantly practise malevolence do not reach [these] three [orders of]

\footnotetext{
28 貪財色災及胞中; Taiping jing DZ 1101, 112.1a (unit 185).

29 Ibid., 112.2b.

30 The standard reference in a Western language is Barbara Hendrischke, "The Concept of Inherited Evil in the Taiping Jing," East Asian History 2 (1991).
} 
longevity - all die prematurely. Those who die an embryo in the womb as well as underage persons are called "innocents inheriting the burden of [their] forefathers' transgressions." ${ }^{31}$

如行善不止, 過此壽, 謂之度世. 行惡不止, 不及三壽, 皆夭也. 胞胎及未 成人而死者, 謂之無幸承負先人之過。

The importance of the passage, though belonging to a later (Tang or even Song) textual stratum of the Great Peace corpus, should not be underrated. ${ }^{32}$ Not only does it confirm, for our present purpose, the belief in prenatal death being caused by the after-effects of ancestral deeds, it also provides us with a - supposedly - early definition of the compound dushi 度世, frequently misunderstood as "salvation" under the influence of Buddhist terminology. ${ }^{33}$ It also makes clear that individual lifespan is dependent on moral conduct. ${ }^{34}$

\section{$4 \quad$ Birth and Beyond}

Even if gestation is symbolically presided over by Yin rather than Central Harmony, as we have seen, the latter must still be logically correlated with the product of the union of all instantiations of Yin and Yang. Such is indeed the case in the human triads encountered throughout the Great Peace corpus: a child $(z i$ 子) is brought forth by the union of a mother ( $m u$ 母) or wife ( $f u$ 婦), who are two equivalent Yin correlates, and a father ( $u$ 父) or husband ( $f u$ 夫) - two equivalent Yang correlates.

In a section of the Taiping jing chao bearing the pseudo-title "Harmonising the Three Pneumata and Promoting the Sovereign" ("He sanqi xing diwang 和

$31 \quad$ Taiping jing chao DZ 1101, 2.12a (yi bu 乙部).

32 For the possible date of the source materials used to compile the Taiping jing chao, see Grégoire Espesset, "The Date, Authorship, and Literary Structure of the Great Peace Scripture Digest," Journal of the American Oritental Society 133.2 (2013).

33 Compare William E. Soothill and Lewis Hodous, eds., A Dictionary of Chinese Buddhist Terms: With Sanskrit and English Equivalents and a Sanskrit-Pali Index (London: Kegan Paul, Trench, Trubner, 1937), 301: "To get through life; to pass safely through this life. Also, to save the world."

34 For all these matters, see Grégoire Espesset, "Criminalized Abnormality, Moral Etiology, and Redemptive Suffering in the Secondary Strata of the Taiping jing," Asia Major 15.2 (2002a), especially 42, n. 221, for different sets of lifespan duration expressed in different parts of the Great Peace corpus. 
三氣興帝王"), ${ }^{35}$ Central Harmony corresponds to the "newborn child" (chizi 赤子). The passage goes on to state that children are born thanks to their father and mother, but they specifically depend on their father for their life mandate (ming 命) while their mother is solely entrusted with their birth (sheng 生). Incidentally, in the same paragraph we learn that the union of the three pneumata (Yin, Yang, Central Harmony) in turn brings forth "Great Harmony" (taihe 太和), which eventually produces the "Pneuma of Great Peace" (taiping zhi qi 太平之氣), in other words, the very principle of universal equilibrium. ${ }^{36}$

In Chinese, "newborn child" literally reads "bright red (vermillion) child" with red being, in the Five Agents correlative system, the colour of the Fire agent, the heart viscus, the south, summer, and so on. In the Taiping jing, though, the phrase does not appear to have a symbolic and semantic value comparable to that given it in early Taoist literature. For example, in the meditation practices of the manual known as the Laozizhongjing 老子中經 (Laozi's Central Scripture; DZ 1168), the expression "newborn child" refers to the embryo of immortality or "real person" (zhenren) that each practitioner must visualise within his or her own body in order to achieve transcendence. ${ }^{37}$ But the Taiping jing also correlates the colour red, the Fire agent and the south with the reigning emperor (Great Yang) - the east, the Wood agent, and Young Yang (shaoyang 少陽) being logically emblematic of the imperial heir - and, concomitantly and explicitly, gives the Fire agent predominance over the other four agents. ${ }^{38}$ The strongly political orientation of this ideology significantly departs from the rather neutral equilibrium of the original fivefold system, and yet does not otherwise distort its rationality. As we have seen in the case of pro-Yang and anti-Yin partiality, this aptly shows the way Great Peace ideologists used and adapted the common metaphysical rationale of their time to fit their own concerns. In Great Peace discourse, "vermillion child" could almost designate any

I call "pseudo-title" the opening phrase, in some sections of the Scripture Digest, which appears to derive from a former unit title deprived of its numbering and merged into the body of the text. The Scripture Digest does not use unit titles properly speaking - except on the first page of chapters 1, 4, and 7 (three occurrences in all); see Espesset 2013, 324 .

36 Taiping jing chao Dz 1101, 2.7b (pseudo-title) and 8b (text) (yi bu 乙部).

37 Taishang Laojun zhongjing 太上老君中經 (Most High Old Lord's Scripture of the Centre; DZ 1168), 1.6b-7a. For the date of this version, see John Lagerwey, "Deux écrits taoïstes anciens," Cahiers d'Extrême Asie 14 (2004); Kristofer Schipper and Franciscus Verellen, eds., The Taoist Canon: A Historical Companion to the Daozang (Chicago: University of Chicago Press, 2004), 92-94.

38 See Espesset 2002c, 436-37. 
newborn infant as much as the reigning son of Heaven himself; and even though the extant Taiping jing does not state it plainly, a section from the Taiping jing chao devoted to a longevity practice based on the visualisation of the heart viscus opens with the pseudo-title "There is a Son of Heaven Within Everyone's Abdomen" (“Fanren fuzhong ge you tianzi 凡人腹中各有天子”). ${ }^{39}$

Back to unit 41 of the Taiping jing, we find the ideas of the perfection and completeness of the human body at birth expressed symbolically in terms of pneuma and Yin/Yang being "replete" ( $j u$ 具):

Furthermore, at birth, all people contain Heavenly Pneuma, and come out when replete [with it]. The head, round, is Heaven; the feet, square, are Earth; the four limbs are the four seasons; the five viscera are the Five Agents; the ears, eyes, mouth and nose are the seven regulators [or] the three luminaries..$^{40}$ It is impossible to give a complete account of this; only sage men know such things. At birth, all men are replete with Yin and Yang; when [the appropriate number of] days and months are fulfilled, they open up the womb and emerge from the opening; seeing Heaven and Earth, they resume growing. Together they will perpetuate their forefathers' lineage, help Heaven bring forth beings and help Earth nourish the forms [i.e., physical bodies] [of these beings] ${ }^{41}$

\section{又人生皆含懷天氣, 具逎出. 頭圓, 天也. 足方, 地也. 四支, 四時也. 五藏, 五行也. 耳目口鼻, 七政三光也. 此不可勝紀, 獨聖人知之耳. 人生皆具狯 陽, 日月滿乃開胞而出戶, 視天地當復長, 共傳其先人統, 助天生物也, 助 地養形也。}

This idea that the innate perfection of the human body mirrors cosmic perfection is well documented in early Chinese texts. ${ }^{42}$ Here, however, this innate perfection is understood as the result of the body being "replete" with "Heavenly Pneuma" (tianqi 天氣). Then, only after the completion of an unspecified term (supposedly ten months), when their body is, similarly, "replete" with Yin and

Taiping jing chao DZ 1101, 8.5a-6a (xin bu 辛部). In the Dunhuang table of contents, the first half of the title of unit 218 (chapter 124) is almost identical (see Ms Stein 4226, col. 214: 人腹各有天子文歸赤漢). In all likelihood, the abstracted rendition of the Taiping jing chao derives from the contents of this unit, which is missing in the Scripture proper. The seven regulators (qizheng) are the sun, the moon, and the five planets, or the seven stars of the Dipper; the three luminaries (sanguang) are the sun, moon, and stars. Taiping jing DZ 1101, 35. 8a-b (unit 41); compare Hendrischke 2006, 76.

42 See Yang Jilin 楊寄林, ed., Taiping jing jinzhu jinyi 太平經今注今譯 (Shijiazhuang: Hebei renmin chubanshe, 2002), 84, interlinear note (five references). 
Yang, do human beings come into the world. This view of the human body's functional and symbolic completeness at birth matches the idea of the completion of the temporal process of gestation.

Despite being granted a complete, perfect body, in which Heaven insufflates the breath of life, it does not follow that the newborn child is intellectually different from the prenatal infant. In unit 104 of the Taiping jing we witness the master dispensing an "Admonition to the Six Disciples" (Jie liuzi" 戒六子) as the date of his departure approaches. Although innately endowed by Heaven with the "authentic Way" (zhendao 真道), all people need the guidance (dao 導) of masters to realise their potential, just like newborn children need guidance - and social immersion - to learn and develop:

Therefore, their initiation, guidance, and tuition rest with masters - only then will it be possible to make it that there is nothing [they] do not know. He who does not open up his gate, even though he has received the authentic Way of Heaven, knows not a single thing; he is like an infant who, at birth, would be abandoned in a single room and not guided to study actively: there is nothing he might learn. ${ }^{43}$

故在師開之, 導之, 學之, 則可使無不知也. 不闘其門戶, 雖受天真道, 無 一知也. 比若嬰兒生, 投一室中, 不導學以事, 無可知也。

The Taiping jing chao preserves many fragmentary elements in dialogue style. In these parts, the master is sometimes called a "divine person" (shenren 神人), a feature pointing to a late stratum of the surviving corpus (in what is assumed to be the earliest stratum, he is called "heavenly master," tianshi 天師). ${ }^{44}$ Such is the case in chapter 9, admittedly the rendition of Part 9 (ren bu 壬部), that is, of units 137-53 (whose corresponding sequence in the canonical version of the Taiping jing is missing). One such passage examines how the Heavenly Way "helps" (zhu 助) and “favours" or "blesses" (you 祐) the weak (ruo 弱) and the solitary (gua 寡) rather than the strong (qiang 強) and the multitude (zhong

43 Taiping jing DZ 1101, 68.1a (title) and 2a (text) (unit 104).

44 Hendrischke has stated that the compiler of the Taiping jing chao "avoided" the formula "heavenly master" and used "divine person" instead; see Barbara Hendrischke, "The Dialogues Between Master and Disciples in the Scripture on Great Peace (Taiping jing)," in A Daoist Florilegium: A Festschrift Dedicated to Professor Liu Ts'un-yan on his Eighty-Fifth Birthday, Lee Cheuk Yin and Chan Man Sing, eds. (Hong Kong: The Commercial Press, 2002), 188; and Hendrischke 2006, 349. However, no less than fifteen occurrences of "heavenly master" in the Taiping jing chao disprove this assumption; see Espesset 2013, 332. 
眾) - a very Taoist concern indeed, and yet, here it is expressed in a rather "monist" way, perhaps under the influence of mainstream Confucianism: ${ }^{45}$

For weakness is how the Way operates. Solitude is a requisite of the Way. Thus the Pole Star is solitary, and yet the multitude of stars follows [it ${ }^{46}$ - its loneliness contains the multitude. The requisite of the Way is unity, and yet the Way assembles. This is the reason why the King is the paragon of solitude, and yet the realm helps [him] rule - the effect of [the multitude] helping the single. Fathers and mothers are of utmost strength, and yet they help infants - this is the effect of the strong helping the weak. ${ }^{47}$

夫弱者, 道之用也. 寡者, 道之要也. 故北極一星而眾星屬, 以寡而禦眾也. 道要一而道屬焉. 是故國王極塞, 而天下助而治, 助寡之効也. 父母極強, 反助嬰兒, 是強助弱之効也。

The paragraph quite evidently refers to loci classici from the Daode jing 道德經 (Book of the Way and Virtue), especially section 40, the first half of which is reproduced - a literary allusion rather than a citation, since the source is not named - in the same section of the Taiping jing chao ("for weakness is how the way operates"). Sections 76 ("the solid and strong remain below, the soft and weak dwell above") and 78 ("weakness prevails over strength") are also alluded to. ${ }^{48}$ Interestingly, Great Peace proponents willingly adopted the idea of weakness taking precedence over strength - as illustrated by the image of the child - but they added the very centralising and imperialist notion of multiplicity and periphery being ruled by unity and by the centre.

At birth, the child leaves a pristine environment devoid of differentiation and enters the Yin/Yang pulsating motion of cyclical time. Cycles constitute a wellknown feature of classic Chinese metaphysics. In La pensée chinoise, Marcel

45 The ruler is also likened to the Pole Star in the Lunyu 論語 (Analects), 2. 1; see James Legge, transl., The Chinese Classics, vol. 1, part II (London: Trübner, 1871), 9.

46 Observed from the surface of Earth at night, the starry sky appears to rotate around the Pole Star.

47 Taiping jing chao DZ 1101, 9.3b (ren bu 壬部).

48 Compare Daode zhenjing 道德真經 (Authentic Scripture of the Way and Efficacy; DZ 664), 2.2a (section 40), 11b (section 76), and 12a (section 78); see James Legge, transl., The Texts of Taoism, vol. 1 (London: Oxford University Press, 1891), 83, 118, and 120. 
Granet (1884-1940) wrote that, for the Chinese, "Time seemed to have a cyclical nature," and remarked that "the Chinese representation of Time" was also the representation "of a liturgical order"; he believed this "particular arrangement of Time" to coincide with a "particular arrangement of Space." 49 In the famous chapter from the same work devoted to the importance of numerology in Chinese thought, Granet stressed that the Chinese resort to numbers not merely to organise things, but "to express the qualities of certain groupings or to indicate a hierarchical order."50 The metaphysics of Great Peace aptly illustrates this statement.

Great Peace ideologists widely resorted to numerical symbolism and cycles to construct their worldview. Unit 167 of the Taiping jing, which bears the title "What the Number of Parts in the Scriptural Text Corresponds to" ("Jingwen bushu suo ying 經文部數所應"), uses a tenfold cycle to introduce an explanation of natural numbers from 1 to 10 :

Heaven is the beginning of numbers. Therefore, when Heaven and Earth are not yet separated, accumulated pneumata are all united as one, [then] divide into two, forming husband and wife. Heaven descends and impregnates Earth; gestation [takes place] in boreal obscurity [i.e., the north], [whose] characters are jiazi (S1/B1). ${ }^{51}$ [Plants] spread roots in the northeast, [whose characters are] chou (B2) and yin (B3); emerge in mao (B4) [i.e., the east]; complete sprouting in the southeast, [whose characters are] chen (B5) and si (B6); [let] branches hang in the south and grow in $w u\left(\mathrm{~B}_{7}\right)$; get old in the southwest, [whose characters are] wei (B8) and shen (B9); and [reach] completion in sector the west, [where] the sun sets, in you (B1o). Storage is completed in the northwest, [whose characters are] $x u(\mathrm{~B} 11)$ and hai $(\mathrm{B} 12) .{ }^{52}$

天, 數之始也. 是故天地未分之時, 積氣都合爲一. 分爲二, 成夫婦. 天下 施於地, 懷妊於玄冥, 字爲甲子, 布根東北, 丑與寅, 始見於卯, 畢生東南, 辰與 (己) [巳], 垂枝於南, 養於午, (尚) [向] 老西南, 未與申, 成西方, 日入, 西, 畢藏西北, 戌與亥。

49 See Marcel Granet, La pensée chinoise (Paris: Albin Michel, 1968), 85-86; capitalization is Granet's.

50 Ibid., 128; Granet's emphasis.

51 The numbered abbreviations S and B refer to the sequence of the celestial stems and earthly branches respectively (for example, S1 means "first celestial stem").

$5^{2} \quad$ Taiping jing DZ 1101, 102. 5a (unit 167). 
In this cycle, the first stage corresponds to the pristine phase of cosmogony, before the very formation of Heaven and Earth; the next stage marks the appearance of binary differentiation as, echoing the procreative potentiality of the couple "husband and wife," Heaven fertilises Earth. The ensuing eight stages reflect mostly agricultural activities and concerns, closely following the phases of vegetal development, even though the term usually used to designate plants (as well as beings in general), wu 物, does not appear. Each phase is situated according to the eight directions and marked with the corresponding earthly branch (for cardinal directions) or pair of earthly branches (for ordinal directions). The third phase, in addition to the corresponding earthly branch, is marked with the first heavenly stem; both combine into the first couple of the sexagesimal cycle, jiazi 甲子 $(\mathrm{S} 1 / \mathrm{B1})$, a binomial known to symbolise cosmic renewal.

As we have seen above, Yin is said to preside over gestation. The text is consistent with this idea when explaining that "gestation [takes place] in boreal obscurity," that is, in the north, where Yang reappears within Yin at the peak of Yin's development. According to this logic, procreation is naturally correlated with a specific moment in the cycle, at least symbolically. The mention of the couple "husband and wife" seems to imply that human reproduction is subject to this cycle, just as plant reproduction is. After all, we may recall that the citation from Li Xian's commentary to the Hou Han shu made clear that sexual intercourse must be performed at the proper time, lest the process of impregnation fail.

Let us now turn briefly to a cycle from a supplement to the Yijing 易經 (Classic of Changes) titled Yiwei Qian zuodu 易緯乾鳌度 (Weft of Changes: Regulations Chiselled by Qian), one of the longest extant Weft texts. ${ }^{53}$ This source is assumed to belong to the earliest group of Weft texts. ${ }^{54}$ It survived

53 The tentative English rendering of this title derives from Bent Nielsen's translation ("Chiseling through to the regular system of hexagram Qian") in "Calculating the Fall of a Dynasty: Divination Based on the Qian zuo du," Zhouyi Studies 6.1 (2009-2010). According to Nielsen, the title "should probably be understood along the lines of 'revealing the activities and intentions of heaven." I am grateful to Professor Nielsen for providing me with a copy of this paper.

54 See Yasui Kōzan 安居香山, Isho to Chūgoku no shinpi shisōo 緯書と中國の神秘思想 (Tokyo: Hirakawa shuppansha, 1988), 237. The assumption is that the earliest Weft texts must be those cited in the Baihu tongyi 白虎通義 (Comprehensive Discussions in the White Tiger [Hall]), a source, partly by Ban Gu 班固 (32-92), whose received edition may date back to the first half of the third century; see Michael Loewe, "Pai hu t'ung 白虎通," in Early Chinese Texts: A Bibliographical Guide, ibid., ed. (Berkeley: Society for the Study of Early China and The Institute of East Asian Studies, University of California, 1993). 
together with a commentary ascribed to Zheng Kangcheng 鄭康成, alias Zheng Xuan 鄭玄 $(127-200) .55$ The text discusses the cosmological rationale behind the "changes" ( $y i$ 易) and the eight trigrams (bagua 八卦). One of the passages presented as the sayings of Confucius describes a cycle rather similar to the cycle in unit 167 of the Taiping jing:

Confucius says: "Changes begin with the great pole. The great pole divides into two, thus giving birth to Heaven and Earth. Heaven and Earth are segmented into spring, autumn, winter and summer, thus giving birth to the four seasons. Each one of the four seasons is divided into Yin and Yang - the hard and the soft, thus giving birth to the eight trigrams. The eight trigrams are arranged, the Way of Heaven and Earth is established, and the images of thunder, wind, water, fire, mountain and lake are determined. ${ }^{56}$ They handle affairs separately. [Trigram] Zhen brings forth beings in the eastern sector; it is located in the second month. [Trigram] Xun disperses them in the southeast; it is located in the fourth month. [Trigram] Li makes them grow in the southern sector; it is located in the fifth month. [Trigram] Kun nourishes them in the southwestern sector; it is located in the sixth month. [Trigram] Dui harvests them in the western sector; it is located in the eighth month. [Trigram] Qian bales them in the northwestern sector; it is located in the tenth month. [Trigram] Kan stores them in the northern sector; it is located in the eleventh month. [Trigram] Gen [makes] them terminate and begin [again] in the northeastern sector; it is located in the twelfth month. As the pneumata of the eight trigrams terminate, the divisions into the four cardinal and four ordinal directions are [made] obvious; the Way of birth, growth, harvest, and storage is fulfilled; the substance of Yin and Yang is determined; the

Besides, the Qian zuo du is cited in a memorial submitted to the throne by Bian Shao 邊 韶 in 143, which Cai Yong 蔡匘 (133-192) included in his treatise on “Lüli 律曆” ("Pitch Pipes and the Calendar"), later appended to the Hou Han shu in the "Zhi 志" ("Treatises") section; see Hou Han shu, 2.3035. For the authorship of this treatise, see B.J. Mansvelt Beck, The Treatises of Later Han: Their Author, Sources, Contents and Place in Chinese Historiography (Leiden: Brill, 1990), 61-63.

55 Biography in Hou Han shu, 35.1207-13.

56 The eight trigrams are correlated with the natural elements as follows: Qian/Heaven, Kun/Earth, Zhen/thunder (lei 雷), Xun/wind (feng 風), Kan/water (shui 水), Li/fire (huo 火), Gen/mountain (shan 山) and Dui/lake, or marsh (ze 澤). "Water" and "fire" should be distinguished here from the homographic agents in the fivefold system. 
efficacy of the gods is pervasive; and each of the myriad beings is accomplished according to its category."57

孔子曰: 易始於太極. 太極分而爲二, 故生天地. 天地有春秋冬夏之節, 故 生四時. 四時各有陰陽剛柔之分, 故生八卦. 八卦成列, 天地之道立, 雷風 水火山澤之象定矣. 其布散用事也. 震生物於東方, 位在二月. 巽散之於 東南, 位在四月. 離長之於南方, 位在五月. 坤養之於西南方, 位在六月. 兌收之於西方, 位在八月. 乾制之於西北方, 位在十月. 坎藏之於北方, 位 在十一月. 艮終始之於東北方, 位在十二月. 八卦之氣終, 則四正四維之 分明, 生長收藏之道備, 陰陽之體定, 神明之德通, 而萬物各以其類成 矣。

This passage opens with a classic cosmogony, which in turn introduces an eightfold, annual cycle, whose spatial correlations follow the houtian 後天 (post-celestial) configuration. ${ }^{58}$ As the cycle unfolds, its agricultural import and focus on life becomes clearer. Though formally returning to cosmogony, the concluding sentences stress the importance of agricultural activities throughout the year and of their "fulfillment" as the cycle ends.

Returning to the Taiping jing, unit 139 justifies the cyclical value of the number twelve by stressing the crucial moment when the annual cycle comes to an end and begins anew, on the last and first lunations, respectively:

It is like the myriad beings, which end up dying in hai (B12). [Trigram] Qian, since it marks the commencement [of the cycle], establishes [its] position at the gate of Heaven. ${ }^{59}$ Solidification of semen begins in hai (B12), gestation [takes place] in ren (S9), and the shaping of perceptible form [i.e., physical body] [during] the initial novena in $z i(\mathrm{Bi}),{ }^{60}[\mathrm{as}]$ the

57 Yasui and Nakamura 1971-1992, vol. 1.1 (Ekijōo 易上), 21.

58 Traditionally ascribed to King Wen 文王, it is distinct from the xiantian 先天 (pre-celestial) configuration, ascribed to the mythic ruler Fu Xi 伏羲, which distributes all eight trigrams among sectors differently: Qian/south, Kun/north, Zhen/northeast, Xun/southwest, Kan/west, Li/east, Gen/northwest and Dui/southeast; see Bent Nielsen, A Companion to Yi Jing Numerology and Cosmology: Chinese Studies of Images and Numbers from Han 漢 (202 BCE-220 CE) to Song 宋 (960-1279 CE) (London: Routledge Curzon, 2003), 107-10 and 264-68.

59 The northwest, location of trigram Qian in the post-celestial configuration.

6o "Initial novena" (chujiu 初九) here designates the first of the six months of Yang growth. In the terminology of the Yijing and related texts, it is the name of the first line at the bottom of a hexagram, when the line is Yang (unbroken). 
sun begins to return. ${ }^{61}[\mathrm{At}]$ the second novena in chou (B2), Yin and Yang are set in motion. ${ }^{62}$ [At] the third novena in yin $\left(\mathrm{B}_{3}\right),{ }^{63}$ Heaven, Earth, humans and the myriad beings, all wanting to turn their back to Yin and face Yang, peek in yin (B3). Therefore, the myriad beings begin to spread roots in the northeast and show their head in yin (B3). Among plants, the large ones take Wood as their chief [agent], therefore yin (B3) corresponds to Wood beginning its life - jia $\left(\mathrm{S}_{1}\right)$ best corresponds to the commencement of Wood. ${ }^{64}$ Therefore, the myriad beings appear in jia ( $\left.\mathrm{S}_{1}\right)$ and yin (B3), and they eventually die in gui (S10) and hai (B12). Therefore, Wood, when receiving the mandate [of life], is born of primordial pneuma, ${ }^{65}$ in the middle of Great Yin and Water, and it is therefore initiated by jiazi $(\mathrm{S} 1 / \mathrm{B} 1){ }^{66}$

比若萬物終死於亥. 乾因建初, 立位於天門. 始凝核於亥, 懷妊於壬, 成形 初九於子, 日始還, 九二於丑而陰陽運, 九三於寅, 天地人萬物俱欲背陰 向陽, 闃於寅. 故萬物始布根於東北, 見頭於寅. 物之大者, 以木爲長也, 故寅爲始生木, 甲最爲木之初也. 故萬物見於甲寅, 終死於癸亥. 故木也 乃受命, 生於元氣, 太陰水中, 故以甲子爲初始。

This layered discourse combines three consecutive celestial stems and four consecutive earthly branches, a trigram, three hexagram lines, the solar cycle, Yin and Yang, two of the Five Agents, an ordinal direction, cosmic entities, and stages in the development of plant life. Framed in a four-month period extending from the first lunation of winter to the first lunation of spring, all these

61 "The sun begins to return": the duration of daytime begins to increase again, after the winter solstice.

62 "Yin and Yang are set in motion": Yin is declining and Yang is growing.

63 "Second novena" and "third novena" here refer to the second and third months of Yang growth. In the terminology of the Yijing, the expressions designate the second and third lines of a hexagram - starting from the bottom line - when these lines are Yang (unbroken).

64 In Xu Shen's 許慎 Shuowen jiezi 説文解字 (Explanation of Graphs and Analysis of Characters), completed in 100 C.E., the character jia 甲 is defined as picturing the sprouting of plants in the east (see 308 in the 1963 Zhonghua shuju edition); for the date of this source, see William G. Boltz, “Shuo wen chieh $t z u$ 説文解字” (Berkeley: Society for the Study of Early China and The Institute of East Asian Studies, University of California, 1993), 42942.

65 Yuanqi 元氣, the materia prima of the macrocosm, whence all particularised forms of pneumata proceed.

66 Taiping jing DZ 1101, 93.8a-b (unit 139). 
elements serve to explain the process of renewal, that is, the very dynamic of the cosmic cycle. One of the differences between this cycle and those above is that, although all three share a strongly life-focused discourse, death ( $s i$ 死) appears (twice) in the latter as the ineluctable end of the myriad beings - an end anchored in time. Even though the text deals with plants and the Wood agent, it is tempting, from this example of cyclical logic, to extrapolate the unavoidable nature of death for all living beings, including humans.

Unit 130 of the Taiping jing, bearing the title "Meditation on the Eight Trigrams to Make Essence Return” (“Bagua huanjing nian 八卦還精念”), provides the reader with the means to benefit from the cyclical nature of time rather than passively submitting to it. Its purpose is to describe a fivefold meditation practice based on the Five Agents and their usual correlates (sectors, organs, colours, etc.), plus the Yin/Yang couple, the celestial stems, and the earthly branches. (Interestingly, despite its title, the unit does not mention any trigrams or hexagrams - one of the pieces of internal evidence showing that the received version of the Taiping jing must have gone through a complex editing history.) The literary form used throughout is discursive, as opposed to the dialogue form used in most parts of the Taiping jing. Here is a key passage in this unit, written in quadrisyllabic verse for the most part: ${ }^{67}$

Inner radiance of boreal light,

Grand darkness, numerous pneumata,

At the same position as the kidneys,

Where ren (S9) and gui (S10) are located. ${ }^{68}$

$H a i(\mathrm{~B} 12)$ and $z i(\mathrm{~B} 1)$ are consubstantial

And embrace one another within the cycle. ${ }^{69}$

Peaking Yin brings forth Yang -

It is called the initial novena.

Once they join up, they conceive beings.

Yin comes to a stop and Yang rises.

Impregnation [takes place] in hai (B12),

Gestation [takes place] in ren (S9),

玄明内光
大幽多氣
與 (賢) [腎] 同位
壬之癸
亥子共身
周流相抱
極陰生陽
名爲初九
一合生物
陰止陽起
受施於亥
懷妊於壬

67 The section also includes a few pentasyllables and heptasyllables, some of which appear to be rhymed. For the rhyme patterns of the final part of the section, see Yu Liming 兪理 明, ed., Taiping jing zhengdu 太平經正讀 (Chengdu: Ba Shu shushe, 2001), 282.

68 Boreal light, grand darkness, the kidneys, and both celestial stems ren (S9) and gui (S1o) all correspond to the north and the Water agent.

69 The twelfth earthly branch and the first one, which follow one another as the duodecimal cycle ends and begins again, symbolise Yang appearing again within Yin. 
Proliferation [takes place] in $z i(\mathrm{~B} 1)$.

Generation after generation,

Yang, right in the middle of Yin,

Is brought forth ceaselessly.70
(藩) [蕃?] 滋於子

子子孫孫

陽入除中

其生無已

This poem also focuses on the pivotal moment of the cycle: the end and a new beginning. Technically, the first earthly branch immediately follows the twelfth one, as a dominating Yin reaches its peak and the first particle of Yang appears within it. Once again, this turning point is symbolically correlated with the Water agent and the north, whose darkness, liquid nature and potential fertility (infinite pneumata) echo the fetal milieu. Yet this cycle does not include death. On the contrary, as the unit unfolds, the adept is encouraged to meditate on the entire fivefold sequence and to visualise each of the Five Agents' correlates (organ, coloured pneuma or essence, emblematic animal) in order to eventually suppress all disease, remain unaffected by death, harmonise hierarchical relations and ensure social order - individual and collective achievements ultimately leading to the advent of Great Peace. ${ }^{71}$

It should be noted that, in these cycles, the discourse resorts to graphic and phonetic puns. The characters he 核 (seed) and ren 婎 (gestation) each share a graphic component with hai 亥 (B12) and ren 壬 (S9), respectively, while $z i$ 滋 (proliferation) and $z i$ 子 (which occurs both as the first earthly branch and in the phrase zizi sunsun 子子孫孫) belonged to the same rhyme group "Zhi" 之 in Han times. ${ }^{72}$ Such wordplay is reminiscent of the semiotics of the Shuowen jiezi, the aforementioned first comprehensive work of Chinese graphology. ${ }^{73}$

$70 \quad$ Taiping jing DZ 1101, 89.1a (unit 130); the verse layout is mine.

71 Ibid., 89.1a-2b.

72 I rely here on Luo Changpei 羅常培 and Zhou Zumo 周祖謨, Han Wei Jin Nanbei chao yunbu yanbian yanjiu 漢魏至南北朝韻部演變研究, vol. 1 (Beijing: Kexue chubanshe, 1958), 125; for a reconstructed phonology, see William H. Baxter, A Handbook of Old Chinese Phonology (Berlin: Mouton de Gruyter, 1992), 562-64, Table 10.125.

73 See Rao Zongyi 饒宗頤, “Taiping jing yu Shuowen jiezi 太平經與説文解字,” Dalu zazhi 45.6 (1972); Jens Østergård Petersen, “The Taiping jing and the Shuowen jiezi," In The Master Said: To Study and ... To Søren Egerod on the Occasion of His Sixty-Seventh Birthday, Birthe Arendrup, Simon B. Heilesen and J.Ø. Petersen, eds. (Copenhagen: East Asian Institute, University of Copenhagen, 1990); Françoise Bottéro, "Revisiting the wén 文 and the $z i$ 字: The Great Chinese Characters Hoax," Bulletin of the Museum of Far Eastern Antiquities (Östasiatiska Museet) 74 (2002). 
To the average person and the untrained scholar, these cosmic cycles would certainly seem too strong a natural force to oppose with any hope of success. Some religious adepts, however, believed cyclical time not to be an insurmountable obstacle, and they proposed to use its vital momentum instead. Other adepts, or perhaps more advanced ones in the same communities, advocated to re-enact, through a cluster of practices, the condition of their early life - that is, to regain their prenatal condition.

A paragraph from the Taiping jing chao advises the audience to study ( $x u$ 學) as people did in antiquity. The first step of this study should be to take care of one's "perceptible form" - one's physical body: "First, to appease [one's] perceptible form, start doing so by emulating an infant at play who does not use physical strength but only good intentions." ${ }^{74}$

That one should "emulate an infant" (ru ying'er 如嬰兒) is, of course, reminiscent of section 10 of the Daode jing. Section 20 from the same work further contrasts a light-hearted state of perpetual "infancy" (ying'er) with the materialism, emotionalism, activities, and seriousness of the masses. ${ }^{75}$ The Taiping jing chao shows how Great Peace proponents conceptualised a model for individual practice on the basis of this antisocial attitude and respect for the natural condition of mankind.

But the adept may revert further back still. The master, in his farewell "Admonition to the Six Disciples," defines the "major requisites" (dayao 大要) of the Way by referring to the teachings of the "major sages of antiquity" ( $g u$ zhe dasheng 古者大聖):

Therefore, the major sages of antiquity instructed people to deeply meditate and have far-reaching thoughts, to shut their nine [bodily] apertures, to rest their four limbs, to make themselves chaotic, like a circle without end, and to emulate a child in the womb, without attending affairs. ${ }^{76}$

故古者, 大聖教人深思遠慮, 閉其九戶, 休其四 (使) [肢], 使其渾沌, 比若 環無端, 如胞中之子而無職事也。

先以安形, 始爲之, 如嬰兒之遊. 不用筋力, 但用善意; Taiping jing chao DZ 1101, 5.13b (wu bu 戊部).

Daode zhenjing Dz 664, 1.3a (section 10) and 5b (section 20); see Legge 1891, 53-54 and $62-63$.

$76 \quad$ Taipingjing, $68.1 \mathrm{~b}$ (unit 104). 


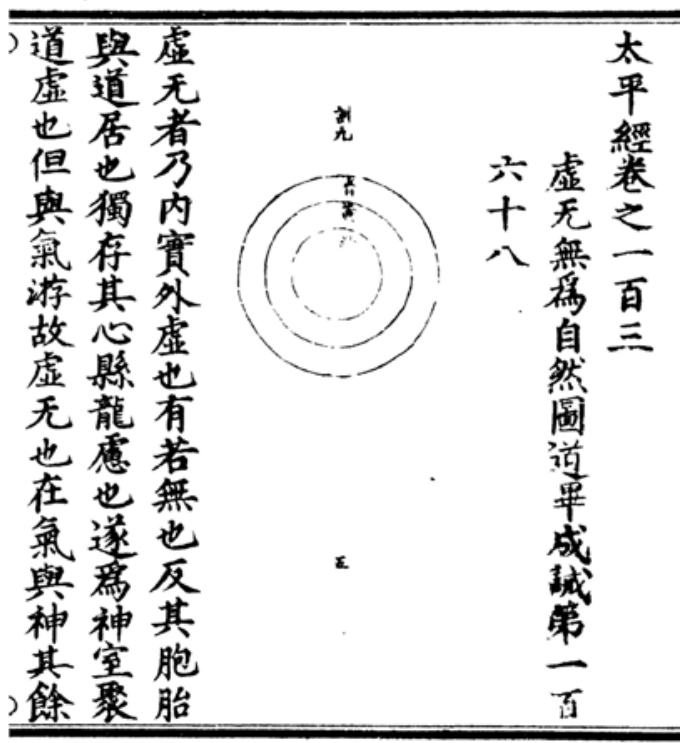

FIGURE 1.1

Illustration preceding the paragraph on "nothingness." The three concentric circles are marked with the words for the colours green, yellow, and red; from Taiping jing 太 平經 (Great Peace Scripture; DZ 1101), chapter 103, unit 168, 1 .

In this passage, the model to emulate is not the postnatal infant but the unborn child - a human being not yet plunged into the cyclical time of Yin and Yang.

Unit 168, entitled "Illustrations of Nothingness, Non-Interference, and Spontaneity [to] Entirely Complete the Way" ("Xuwu wuwei ziran tu dao bicheng 虛无無爲自然圖道畢成”), includes three illustrations - a rare occurrence in the Taiping jing. Each illustration comes with a short text, partly rhymed, and composed in irregular heptameter verse. The entire unit is intended for the purpose of meditation and visualisation. The first paragraph is an exhortation to preserve pneuma (qi), divinity (shen 神), and essence (jing 精), which are one's three vital principles. It includes the urge to "revert to one's [former condition as] an embryo in the womb, dwelling with the Way" (see Fig. 1.1). ${ }^{77}$

The second paragraph shows the benefits of "non-interference" (wuwei 無為) and exhorts the adept to “keep to unity" (shouyi 守一), referring to a practice common to several traditions and texts, including the Great Peace corpus (Fig. 1.2). ${ }^{78}$

77 反其胞胎、與道居也; ibid., 103.1a (unit 168).

78 See Grégoire Espesset, "Les Directives secrètes du Saint Seigneur du Livre de la Grande paix et la préservation de l'unité," T'oung Pao 95.1-3 (2009). 


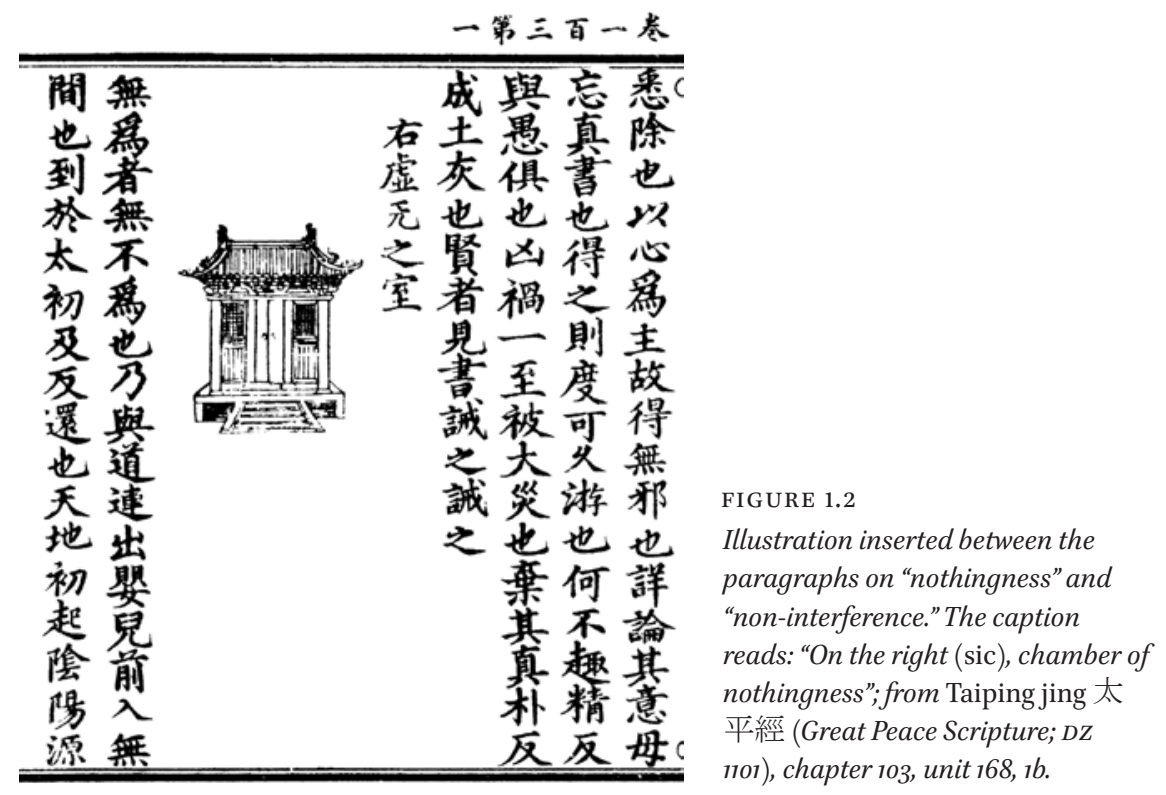

The same paragraph, in all likelihood borrowing its material from section 43 of the Daode jing, praises the unborn infant for its capacity to "penetrate [where] there is no interstice" (ru wujian ye 入無間也). ${ }^{79}$

Unit 63 of the Taiping jing entitled "Vassals, Children and Disciples of Superior Goodness Obtain Recipes of Immortality for [Their] Lord, Father and Master" ("Shangshan chen, zi, dizi wei jun, fu, shi de xianfang 上善臣子弟子為 君父師得仙方”), discusses the most commendable conduct of vassals vis-à-vis their lord, children with respect to their parents, and disciples toward their master. According to the author, once vassals and children adopt the right behaviour, the emperor's rule will bring joy to the people and cosmic balance will be restored. Thereafter, a series of auspicious events will occur, one of which is described as "the eldest reverting to infancy, not knowing how to be malevolent anymore." 80 The notion of reverting to infancy is reminiscent, once again, of a line from section 28 of the Daode jing. ${ }^{81}$ However, to the pristine

\footnotetext{
79 Taiping jing DZ 1101, 103.1a, 1b, 2b (illustrations); 103.1a-b (text) (unit 168). For the chapter's rhyme patterns, see Yu Liming 2001, 376-78. Compare Daode zhenjing Dz 664, 2.2b (section 43), particularly the sentence 無有入於無間; Legge 1891, 87 .

80 上老到于嬰兒, 不知復爲惡; Taiping jing DZ 1101, 47.3a-b (unit 63).

81 復歸於嬰兒; Daode zhenjing Dz 664, 1.8a (section 28); see Legge 1891, 71.
} 
state of the newborn child before differentiation, Great Peace ideology has added the moral value of innate goodness.

Owing perhaps to the personal interests of its unnamed compiler, if not to the contents of the version of the Taiping jing where its material comes from, the Taiping jiang chao has preserved several paragraphs dealing more or less explicitly with the notion and practice of reversion to infancy; for example, the following passage, which would seem to have been formerly composed in heptameter verse and is still rhymed:

Value solely spontaneity - perceptible form and divinity keep to each other.

These two mutually embrace one another.

He who has singular thoughts is, on the contrary, at fault.

Lose spontaneity and you cannot [achieve] longevity.

The five essences ${ }^{82}$ of infancy return to preserve oneself. ${ }^{83}$

\section{獨貴自然, 形神相守 \\ 此兩者, 同相抱 \\ 其有咅思反爲各 \\ 子失自然不可壽也 \\ 嬰兒五精還自保也}

This inversion of the aging process is summed up in another passage, also missing from the canonical Taiping jing but preserved in the Taiping jing chao. Rhymed and composed in heptameter verse like the passage cited above, these lines were likely intended for recitation: ${ }^{84}$

Eyes closed, look inward and come into contact with divinities.

Numinous, not emitting words, on a par with the Way.

Yin and Yang overturning one another is what Heaven has established.

The art of long life can open eyes.

Do not force back feelings, you should be harmonious and magnanimous.

Heaven and Earth are harmonised, and as if they were blind and deaf. [You] want to know its meaning? The child in the womb,

\footnotetext{
82 The "five essences" are presumably those of the five viscera.

83 Taiping jing chao DZ 1101, 6.3a (ji bu 己部); the verse layout is mine. For the rhyme pattern of the paragraph, see Yu Liming 2001, 275.

84 For the rhyme pattern of the paragraph, see Yu Liming 2001, 163 .
} 
Not eating [for] ten months and in contact with divinities, The Way of spontaneity, unsurpassed, Unseeing - and yet the dwelling of pneuma is twelvefold. ${ }^{85}$ Therefore, revert to infancy, and then there will be nothing ominous, Old age will return to youth, in contact with the Way. For this reason paint images twelve times. ${ }^{86}$ The righteous obtain goodness, the unworthy ${ }^{87}$ only the ominous. The heavenly Way is perennial; it cannot cease to be, In the manner of the four seasons, circling back to [its] native place, Old age reverts to the beginning, thus [attaining] long life. ${ }^{88}$

\author{
瞑目内視與神通 \\ 靈不出言與道同 \\ 陰陽相覆天所封 \\ 長生之術可開眸 \\ 子無強腸宜和弘 \\ 天地受和如暗壟 \\ 欲知其意胞中童 \\ 不食十月神相通 \\ 自然之道無有上 \\ 不視而氣宅十二重 \\ 故反嬰兒則無凶 \\ 老還反少與道通 \\ 是故畫像十二重
}

85 According to recent Chinese commentaries, this would refer either to a twelvefold division of the body, or to the circulation of pneuma in accordance with the twelve months of a year; see Long Hui 龍晦 et al., eds., Taiping jing quanyi 太平經全譯 (Guiyang: Guizhou renmin chubanshe, 2000), 397, n. 9; and Yang Jilin, 2002, 452, interlinear note.

86 Dunhuang manuscript Stein 4226 (col. 121) suggests that this passage is the abridged rendition of the now lost chapter 79, whose title was “Baotai yinyang tu 胞胎陰陽 (畗) [圖]") ("Illustration of the Embryo in the Womb, Yin and Yang") and which presumably consisted of both written and visual materials. Images or portraits (xiang 像) may be those of divinities or emblems corresponding to the twelve months or earthly branches, to be drawn by the adept during the practice, probably as support for visualisation.

87 Buxiao 不肖, literally: [those] not following the moral standards of their parents and ancestors.

88 Taiping jing chao DZ 1101, 4.1a-b (ding bu 丁部); the verse layout is mine. The present translation supersedes the former one (in French) I proposed in "À vau- l'eau, à rebours, ou l'ambivalence de la logique triadique dans l'idéologie du Taiping jing," Cahiers d'Extrême-Asie 14 (2004): 80. 


\section{正者得善不肖獨凶 \\ 天道常在不得喪亡 \\ 狀如四時周反鄉 \\ 終老反始故長生也}

The poem insists on the pristine station of the embryo - its spontaneous contact with the Way and the divine - and makes "long life" (here understood as reversion to youth) fully compatible with the inextinguishable, self-regenerative nature of cyclical time, while stressing that moral qualities are essential for the practice to be successful.

A seventh- or eighth-century anonymous Taoist encyclopedia, the Daodian lun 道典論 (Discussion of the Standard Works of Taoism; DZ 1130), cites several passages from the Taiping jing that are lacking in the received version. ${ }^{89}$ One such citation explains what the embryo, "not eating for ten months," draws sustenance from, namely, $q i$ 白. But, here, the word refers certainly less to metaphysical pneuma than to the physiological act of breathing:

'May I ask - how is it that the child, at the embryonic stage, does not eat but breathes?'

'[In] the heavenly Way, there is a "breathing of spontaneity," and then there is a "breathing of elimination and intake." Generally, the breathing achieved while in the womb is the breathing of spontaneity of the heavenly Way. After birth, breathing [consists of] exhaling and inhaling Yin and Yang; this is the breathing of elimination and intake. Those who, once adults, keep to the Way and strive to study, revert to the breathing of spontaneity, and live; those who keep to the breathing of elimination and intake, die. Therefore, those who achieve the authentic Way are able to breathe internally and not breathe externally. By means of this internal breathing, [they] nourish their nature and, subsequently, are able to revert to infancy and restore their [life] mandate. Thus [one] ought to practise internal breathing in order to nourish one's corporeal form from the inside. 90

請問胎中之子, 不食而墨者, 何也?

\footnotetext{
89 For the date of this canonical source, see Ren Jiyu 任繼愈 and Zhong Zhaopeng 鍾肇鵬, eds., Daozang tiyao 道藏提要 (Beijing: Zhongguo shehui kexue chubanshe, 2005), 538; Schipper and Verellen 2004, 445-46 (H.-H. Schmidt).

$90 \quad$ Daodian lun $\mathrm{DZ} 1130,4.8 \mathrm{~b}$. The dialogue layout is mine.
} 
天道迺有自然之点, 廼有消息之点. 凡在胞中且而得点者, 是天道自然之 点也. 及其已生, 嘘吸陰陽而点者, 是消息之㶨也. 人而守道力學, 反自然

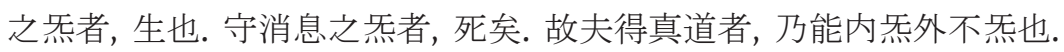
以是内否養其性, 然後能反嬰兒, 復其命也. 故當習内否以内養其形體.

In the Daodian lun, the citation appears in a section on "embryonic breathing" (taixi 胎息), an exercise said to consist of emulating the breathing of the child in the womb - that is, breathing through the nose and not through the mouth, and amassing breath. This practice is quite well known from a number of sources. ${ }^{91}$ Also worth noting is the fact that the literary form of the 125 -character-long citation is dialogue, while the rendition of the same passage in the Taiping jing chao is discursive and has only 57 characters in all ( $45.6 \%$ of the citation in the Daodian lun). ${ }^{92}$

\section{Concluding Remarks}

Great Peace triadic logic is the synthetic extension of the dialectics of Yin and Yang, and the theory of general threefold complementarity and cooperation (after the Heaven-Earth-Human model) is solidly embedded in a dualistic worldview. However, as I have shown elsewhere, Great Peace duality departs from the concept of a universal equilibrium between two ethically equivalent (neutral) forces by adding moral and hierarchical values on both sides of the scale: Yang now embodies good, superiority, and pre-eminence, while Yin typifies evil, inferiority and subordination..$^{93}$ Great Peace views of procreation basically reflect the same logic when they exaggerate the importance of the masculine role, as far as the process of fertilisation is concerned. This ideology remarkably departs from Laozi's emphasis on masculinity and femininity as balanced, complementary qualities to preserve jointly. ${ }^{94}$

91 See Fabrizio Pregadio, ed., The Encyclopedia of Taoism (London: Routledge, 2008), 953-54 (C. Despeux).

92 Taiping jing chao $\mathrm{DZ}$ 1101, 8.19b-20a ( $x$ in bu 辛部).

93 See Espesset 2004.

94 Masculinity and femininity are explicitly balanced throughout the Daode jing. Later exegetes gave femininity pre-eminence over masculinity in some of their commentaries, whence the tendency of some modern scholars to fantasise, "without any hesitation," that "the body of the Tao is a woman's body," and that "the masters, initiators in the art of Long Life, must cultivate a feminine personality"; citing Kristofer Schipper, The Taoist Body (Chicago: The University of Chicago Press, 1993), 129. 
As regards gestation, we find a comparable bias against Yin, depicted as a retaliatory force. And yet, the same material shows an acute understanding of the common nature of the metaphysical principles animating all forms of life. Indeed, Great Peace ideology often deals with humans, animals and plants on the same level. Unit 190 is a case in point. The master stresses that all living beings contain primordial pneuma (yuanqi 元氣), including all cereals, herbs and trees, animals - either crawling, walking, flying, or swimming - and the livestock used by men for sacrifices and sustenance. He urges his disciples "not to kill [those animals] that have an assigned use, neither young [animals]"95 nor "[female animals] gestating [their young] in [their] womb. [When a progeny] should be born but, on the contrary, dies, this entails the termination of a [life] mandate." ${ }^{96}$ It is Heaven that is compassionate regarding all forms of suffering - including the terror felt by domestic animals about to be slaughtered; it is Heaven that "has implemented prohibitions, and offenders will be indicted." ${ }^{\prime 7}$ This religious translation of a poignant awareness of life's frailty denotes an attitude towards Yin which is less radical than one might expect after reading some of the passages cited above; as does the extreme, filial care that humans should have for their mother Earth, which is, after all, the cosmic embodiment of Yin par excellence.

As the binary pattern expands to become a triadic one, neutrality, both moral and metaphysical, is regained, through the elaborate concept of Central Harmony (zhonghe). Generated by the "harmonious union" (hehe 和合) of Yin and Yang "in the middle," hence the name, Central Harmony evens out the radical polarity of its dual progenitors. Likewise, the prenatal embryo is at the same time a harmonious product of Yin and Yang and, because it is still unaffected by the ultimately lethal Yin/Yang rhythm of postnatal life, an exemplar of primeval perfection. Central Harmony clearly occupies a conceptual space beyond the stage of Yin/Yang radical polarity, for better (as embodying unity regained) or for worse (as being a step further in sequences of decline from the undifferentiated Way). ${ }^{98}$

Cycles - either based on lunation, the seasons, agricultural activities, the Five Agents, Yin/Yang, or the eight trigrams - also follow a general, twofold

\footnotetext{
95 勿殺任用者, 少齒者; Taiping jing DZ 1101, 112. 20a (unit 190).

96 懷妊胞中, 當生反死, 此爲絕命; ibid., 112. 20a-b (unit 190).

97 爲施防禁, 犯者坐之; ibid., 112. 2ob (unit 190).

98 For examples of such sequences of decline, see Espesset 2004, 75-76; and my "Revelation Between Orality and Writing in Early Imperial China: The Epistemology of the Taiping jing," Bulletin of the Museum of Far Eastern Antiquities (Östasiatiska Museet) 74 (2002): 83 and 85 .
} 
pattern of concurrent and alternate expansion and recession. All life forms, including human beings, must submit to this cyclical rhythm and conform their activities to each consecutive phase, or be prepared to incur a series of adverse consequences, as the master explains in unit 60 of the Taiping jing, on the occasion of his analysis of the "Punishment and Efficacy" (xing de 刑德) cycle. ${ }^{99}$ Despite such impositions, the enlightened and persevering adept may benefit from the intrinsic, vital momentum of cyclical time so as to transcend its deadly propensity. Transposed in terms of cosmogony, this means leaving the stage of Yin/Yang differentiation and returning to primordial Chaos; in terms of ontology, reverting to the state of an embryo.

\section{Works Cited}

\section{Primary Sources}

Daode zhenjing 道德真經 [Authentic Scripture of the Way and Efficacy]. Dz 664. Hou Han shu 後漢書 [Book of the Later Han]. Fan Ye 范瞱 (398-445). Beijing, Zhonghua shuju, 1987 .

Chōshü Isho shūsei 重修緯書集成 [Revised Collection of Weft Writings]. Yasui Kōzan 安居香山 and Nakamura Shōhachi 中村璋八, eds. Tokyo: Meitoku shuppansha, 1971-1992.

Taiping jing quanyi 太平經全譯 [A Full Translation of the Great Peace Scripture]. Long Hui 龍晦, Xu Xiangling 徐湘靈, Wang Chunshu 王春淑 and Liao Yong 廖勇, eds. Guiyang: Guizhou renmin chubanshe, 2000.

Shuowen jiezi 説文解字 [Explanation of Graphs and Analysis of Characters]. Xu Shen 許慎 (ca. 58-ca. 147). Beijing: Zhonghua shuju, 1963.

Taiping bu juan di er 太平部卷第二 [Great Peace Part, Chapter 2]. Ms. Stein 4226, The British Library, London.

Taiping jing 太平經 [Great Peace Scripture]. DZ 1101, 35-119.

Taiping jing chao 太平經鈔 [Great Peace Scripture Digest]. DZ 1101, 1-10.

Taishang Laojun zhongjing 太上老君中經 [Most High Old Lord's Scripture of the Centre]. DZ 1168.

99 See Yu Tao 于濤, “Taiping jing xingde tushi de yixue biaoxian ji qita 太平經刑德圖式的 易學表現及其他," Zhouyi yanjiu 42.4 (1999). The xing/de cycle in the Great Peace Scripture should be distinguished from the mantic xing/de system of the pre- and early imperial eras discussed in Marc Kalinowski, "Astrologie calendaire et calcul de position dans la Chine ancienne. Les mutations de l'hémérologie sexagésimale entre le $\mathrm{IV}^{\mathrm{e}}$ et le $\mathrm{II}^{\mathrm{e}}$ siècle avant notre ère," Extrême-Orient Extrême-Occident 18 (1996). 
Taiping jing jinzhu jinyi 太平經今注今譯 [Modern Commentary and Translation of the Great Peace Scripture]. Yang Jilin 楊寄林, ed. Shijiazhuang: Hebei renmin chubanshe, 2002.

Taiping jing zhengdu 太平經正讀 [Corrected Reading of the Great Peace Scripture]. Yu Liming 俞理明, ed. Chengdu: Ba Shu shushe, 2001.

Yiwei Qian zuodu 易緯乾鏊度 [Weft of Changes: Regulations Chiselled by Qian]. In Chōshū Isho shūsei, vol. 1.1 (Eki jō 易上). Yasui and Nakamura, eds. Tokyo: Meitoku shuppansha, 1981.

\section{Secondary Sources}

Baxter, William H. 1992. A Handbook of Old Chinese Phonology. Berlin: Mouton de Gruyter.

Boltz, William G. 1993. “Shuo wen chieh tzu 説文解字.” In Early Chinese Texts: A Bibliographical Guide, Michael Loewe, ed., 429-442. Berkeley: Society for the Study of Early China and The Institute of East Asian Studies, University of California.

Bottéro, Françoise. 2002. "Revisiting the wén 文 and the zi 字: The Great Chinese Characters Hoax." Bulletin of the Museum of Far Eastern Antiquities (Östasiatiska Museet) 74: 14-33.

Dufour, Dany-Robert. 1990. Les Mystères de la trinité. Paris: Gallimard.

Dull, Jack L. 1966. "A Historical Introduction to the Apocryphal (Ch'an-wei) Texts of the Han Dynasty." PhD dissertation, University of Washington, Seattle.

Espesset, Grégoire. 2013. “The Date, Authorship, and Literary Structure of the Great Peace Scripture Digest." Journal of the American Oriental Society 133.2: 321-351.

_. 2009. "Les Directives secrètes du Saint Seigneur du Livre de la Grande paix et la préservation de l'unité." T'oung Pao 95.1-3: 1-50.

_ 2008-2009. "Le Livre de la Grande paix et son corpus: Histoire et structure littéraires, idéologie." Annuaire de l'École pratique des hautes études (EPHE), Section des sciences religieuses 117 : 39-47.

_. 2004. "À vau-l'eau, à rebours, ou l'ambivalence de la logique triadique dans l'idéologie du Taiping jing." Cahiers d'Extrême-Asie 14: 61-94.

_ 2002a. "Criminalized Abnormality, Moral Etiology, and Redemptive Suffering in the Secondary Strata of the Taiping jing." Asia Major 15.2: 1-50.

_ 2002b. "Revelation Between Orality and Writing in Early Imperial China: The Epistemology of the Taiping jing." Bulletin of the Museum of Far Eastern Antiquities (Östasiatiska Museet) 74: 66-100.

— 2002c.“Cosmologie et trifonctionnalité dans l'idéologie du Livre de la Grande paix (Taiping jing)." PhD dissertation, Université Paris Diderot-Paris 7, Paris.

Granet, Marcel. 1968 (1934). La pensée chinoise. Paris: Albin Michel.

Hendrischke, Barbara. 2006. The Scripture on Great Peace: The Taiping jing and the Beginnings of Daoism. Berkeley: The University of California Press. 
2002. "The Dialogues Between Master and Disciples in the Scripture on Great Peace (Taiping jing)." In A Daoist Florilegium: A Festschrift Dedicated to Professor Liu Ts'un-yan on his Eighty-Fifth Birthday, Lee Cheuk Yin and Chan Man Sing, eds., 185234. Hong Kong: The Commercial Press.

- 1991. "The Concept of Inherited Evil in the Taiping Jing." East Asian History 2: 1-30.

Kalinowski, Marc. 1996. "Astrologie calendaire et calcul de position dans la Chine ancienne. Les mutations de l'hémérologie sexagésimale entre le $\mathrm{IV}^{\mathrm{e}}$ et le II ${ }^{\mathrm{e}}$ siècle avant notre ère." Extrême-Orient Extrême-Occident 18: 71-113.

Lagerwey, John. 2004. "Deux écrits taoïstes anciens." Cahiers d'Extrême Asie 14: 139-71. Legge, James, transl. 1891. The Texts of Taoism, vol. 1. London: Oxford University Press. , transl. 1871. The Chinese Classics, vol. 1. London: Trübner.

Libbrecht, Ulrich. 1990. "Prāna = pneuma = ch'i?" In Thought and Law in Qin and Han China: Studies Dedicated to Anthony Hulsewé on the Occasion of his Eightieth Birthday, Wilt L. Idema and Erik Zürcher, eds., 42-62. Leiden: Brill.

Loewe, Michael. 1993. "Pai hu t’ung 白虎通." In Early Chinese Texts: A Bibliographical Guide, Michael Loewe, ed., 347-356. Berkeley: Society for the Study of Early China and The Institute of East Asian Studies, University of California.

Luo Changpei 羅常培 and Zhou Zumo 周祖謨. 1958. Han Wei Jin Nanbei chao yunbu yanbian yanjiu 漢魏至南北朝韻部演變研究 [A Study of the Evolution of Rhyme Groups in the Han, Wei, Jin, Southern and Northern Dynasties], vol. 1. Beijing: Kexue chubanshe.

Mansvelt Beck, B.J. 1990. The Treatises of Later Han: Their Author, Sources, Contents and Place in Chinese Historiography. Leiden: Brill.

Nielsen, Bent. 2009-2010. "Calculating the Fall of a Dynasty: Divination Based on the Qian zuo du." Zhouyi Studies 6.1: 65-107.

-2003. A Companion to Yi Jing Numerology and Cosmology: Chinese Studies of Images and Numbers from Han 漢 (202 BCE-220 CE) to Song 宋 (96o-1279 CE). London: Routledge Curzon.

Petersen, Jens Østergård. 1990. "The Taiping jing and the Shuowen jiezi." In The Master Said: To Study and ... To Søren Egerod on the Occasion of His Sixty-Seventh Birthday, Birthe Arendrup, Simon B. Heilesen, and J.Ø. Petersen, eds., 139-149. Copenhagen: East Asian Institute, University of Copenhagen.

Pregadio, Fabrizio, ed. 2008. The Encyclopedia of Taoism. London and New York: Routledge.

Rao Zongyi 饒宗頣. 1972. “Taiping jing yu Shuowen jiezi 太平經與説文解字 [The Great Peace Scripture and Explanation of Graphs and Analysis of Characters]." Dalu zazhi 大陸雜誌 $45 \cdot 6:$ 39-41. 
Ren Jiyu 任繼愈 and Zhong Zhaopeng 鍾肇鵬, eds. 2005. Daozang tiyao 道藏提要 [A Conspectus of the Taoist Canon], third edition. Beijing: Zhongguo shehui kexue chubanshe.

Schipper, Kristofer (Karen C. Duval, transl.). 1993. The Taoist Body. Berkeley: The University of California Press.

Schipper, Kristofer, ed. 1975. Concordance du Tao-tsang: Titres des ouvrages. Paris: École Française d'Extrême-Orient.

Schipper, Kristofer and Franciscus Verellen, eds. 2004. The Taoist Canon: A Historical Companion to the Daozang. Chicago and London: The University of Chicago Press.

Soothill, William E., and Lewis Hodous, eds. 1937. A Dictionary of Chinese Buddhist Terms: With Sanskrit and English Equivalents and a Sanskrit-Pali Index. London: Kegan Paul, Trench, Trubner.

Yasui Kōzan 安居香山. 1988. Isho to Chūgoku no shinpi shisō 緯書と中國の神秘思想 [Weft Writings and the Mystical Thought of China]. Tokyo: Hirakawa shuppansha.

Yu Tao 于濤. 1999. “Taiping jing xingde tushi de yixue biaoxian ji qita 太平經刑德圖式 的易學表現及其他 [The Great Peace Scripture's Punishment/Efficacy Pattern as Expressing the Scholarship of Changes, and Other]." Zhouyi yanjiu 周易研究 42.4: $43-48$. 